\title{
A tribe as an economic actor: The Cihanbeyli tribe and the meat provisioning of İstanbul in the early Tanzimat era
}

\author{
Yonca Köksal and Mehmet Polatel
}

\begin{abstract}
This article studies how the Cihanbeyli tribe became a crucial economic actor for the meat supply of İstanbul, by focusing on a conflict between the tribe's leader, Alişan Bey, and the Russian trader David Savalan, which lasted from the 1840s to the 1850s in and around the province of Ankara. Two important processes of the early Tanzimat era had an impact on the Cihanbeyli's role in animal trade. First, as part of the centralization project of the Tanzimat, the Cihanbeyli tribe was sedentarized in the 1840s and 1850s. Second, although the Ottoman state adopted liberal economic policies during the Tanzimat, the provisioning of meat to the imperial capital continued until 1857. Therefore, the article examines the Cihanbeyli's role in the animal trade in the light of these administrative and economic changes. Our findings support the argument that tribes were an integral part of the imperial economy, politics, and society. The dependence of the Ottoman state on the supply of meat by the Cihanbeyli increased significantly from the seventeenth to the mid-nineteenth century. This opposes the conventional view that posits tribes as primordial forms hindering economic and social development in the modernization processes of the nineteenth and twentieth centuries.
\end{abstract}

Keywords: Meat provisioning; animal trade; state reforms; Tanzimat; Cihanbeyli tribe; Ottoman Empire

\section{Introduction}

The literature on tribes in the Ottoman Empire (and in the Middle East in general) frequently defines them in relation to state structures. The scholarly legacy of Ibn Khaldun assumes an evolutionary process between tribes and states,

\footnotetext{
Yonca Köksal, Department of History, Koç University, Rumelifeneri Yolu 34450, Sarıyer, İstanbul, Turkey; ykoksal@ku.edu.tr.

Mehmet Polatel, USC Shoah Foundation Center for Advanced Genocide Research, 650 West 35th St., LoS Angeles, CA 90089-2571; polatel@usc.edu.
} 
one in which tribes are in constant struggle with state rulers. From this perspective, tribes usually get defined as primordial forms that are somehow anachronistic and doomed to disappear: they are, eventually, to be transformed into settled and urban forms. ${ }^{1}$ Recent studies, however, acknowledge the coexistence of tribes and modern nation-states in the contemporary world, arguing that "tribes did not necessarily cease to exist because states were formed." 2

In the nineteenth century, the centralizing Ottoman state vigorously attempted to settle nomadic and semi-nomadic tribes ${ }^{3}$ in Anatolia, as well as in the Kurdish and Arab provinces. Both the Ottoman authorities in this period and the modern scholarly literature on nomadic and semi-nomadic tribes considered them a challenge to the state in many respects. They disrupted economic activity by plundering villages and robbing peasants. Settlement, on the other hand, would generate an agricultural surplus, taxation revenue for the treasury, and soldiers for the Ottoman army. In other words, settlement would turn nomadic and semi-nomadic tribes disruptive to economic activity into economic actors capable of contributing to different sectors of production. ${ }^{4}$ While emphasizing the benefits of sedentarization, such studies and their approach have not addressed the disadvantages that might emerge with the disappearance of tribes' earlier economic functions, such as stock farming and transportation.

This article challenges the perspective that places nomadism in opposition to settled communities and considers sedentarization advantageous for economic activity. Rather than viewing nomadic and semi-nomadic tribes as bellicose, chaotic organizations, it instead argues for the well-developed trade activity and network of the Cihanbeyli tribe, who were intertwined with Ottoman authorities both in İstanbul and in the province of Ankara.

1 From Émile Durkheim to Karl Marx to Ernest Gellner, the idea that the mobile tribe represents a primordial form in opposition to civilization has long prevailed. For a discussion of this idea, see Reşat Kasaba, $A$ Moveable Empire: Ottoman Nomads, Migrants and Refugees (Seattle: University of Washington Press, 2009), 21-22.

2 Philip S. Khoury and Joseph Kostiner, eds., Tribes and State Formation in the Middle East (Berkeley: University of California Press, 1990), 2.

3 In the Ottoman archival sources, tribes are called aşiret, kabile, or boy. With the exception of tribes that were highly mobile over a wide geography, they were usually semi-nomadic groups who migrated between winter and summer pastures, displaying a geographically limited mobility. Cengiz Orhonlu argues that it is wrong to call them "nomadic," since they were involved in animal husbandry in general and in basic cultivation on the winter pastures. Therefore, he uses the term konar-göçer ("semi-nomadic") for them. See Cengiz Orhonlu, Osmanlı Imparatorluğu'nda Aşiretlerin İskânı (İstanbul: Eren, 1987), 13.

4 Two works by Ahmed Cevdet Pasha display Ottoman state officials' approach to tribal settlements; see Ahmed Cevdet Pasha, Mar'ûzât, ed. Yusuf Halaçoğlu (İstanbul: Çağrı Yayınları, 1980), 131-172 and Ahmed Cevdet Pasha, Tezâkir, vol. 3, ed. Şevki Nezihi Aykut, Abdülkadir Özcan, and Mehmet İpşirli (Ankara: Türk Tarih Kurumu, 1991), 107-190. For the Ottoman state's policies about and reasons for tribal settlement, see also Yonca Köksal, "Coercion and Mediation: Centralization and Sedentarization of Tribes in the Ottoman Empire," Middle Eastern Studies 42, no. 3 (2006): 469-491. 
As one of the main meat suppliers for the imperial capital in the early Tanzimat era, the semi-nomadic Cihanbeyli constituted a crucial economic actor. Even so, they became a target of Ottoman settlement policies, and the tribe interacted with and was ultimately incorporated into the larger socioeconomic formation of the Ottoman state.

The discussion below analyzes how the Cihanbeyli became a crucial economic actor for the Ottoman meat supply by focusing on a conflict between the Cihanbeyli's leader, Alişan Bey, and the Russian trader David Savalan, which lasted from the 1840 s to the 1850 s. This debt trial showcases the rich trade networks that existed among the Cihanbeyli tribe, Ottoman state authorities, and moneylenders and merchants from Ankara not only to İstanbul, but also to other regions, such as İzmir and Bursa. While explaining the economic relations of the Cihanbeyli, the article also uses analysis of documents from the Ottoman archives to show how meat provisioning in the imperial capital continued in the period when liberal economic policies were adopted after the 1838 Treaty of Baltaliman1. ${ }^{5}$

The following section addresses theoretical issues such as tribe-state relations, as well as the economic activities of tribes in general and of the Cihanbeyli in particular. Then, we will explain how meat provisioning in İstanbul was maintained before and during the Tanzimat era, followed by a discussion of how the Cihanbeyli became part of this provisioning endeavor. Finally, the article will analyze the debt trial between David Savalan and the Cihanbeyli.

\section{Literature review}

The dichotomy between nomadic tribes and settled communities has frequently been used to explain the former as an autonomous social and economic unified category in isolation from other social and political actors. For example, Hanna Batatu has argued for a wide schism in Iraq dividing the main cities from the tribal countryside. Accordingly, these two occupied yet separate worlds and the connections between them were primarily economic, "[b]ut even in this regard their relationship could scarcely be said to have been vigorous." 6 This understanding of tribes and states as exclusive entities belonging to different stages of evolution has been challenged in recent years. Reşat Kasaba, for instance, has questioned the assumption of a sharp divide between stasis and mobility as respective markers

5 Since there was no British consulate in Ankara during this time period, the documents of the closest British consulate, located in Bursa, were also examined, though they did not provide much information on the issue.

6 Hanna Batatu, The Old Social Classes and the Revolutionary Movement in Iraq (Princeton: Princeton University Press, 1978), 13-14. 
of civilization and barbarism. Instead, he has argued that tribes were incorporated into Ottoman institutions from the beginning of the state's formation. This incorporation continued in the nineteenth-century reform period, which featured constant negotiations and relations between the Ottoman state and tribes. ${ }^{7}$ Similarly, for the case of Iraqi tribes, Samira Haj has stated that it is misleading to consider them as primordial forms in the nineteenth century. On the contrary, she has argued that the tribes were constantly forming and transforming in relation to larger social, economic, and political organizations. She also points out that the tribes had great internal variation and diversity in their external relations with other social groups. ${ }^{8}$

The perspective that considers tribes not as primordial forms, but rather as integrated components of the modernizing forms of institutions, forces us to rethink the economic role of tribes in larger society. While studies on the period before the nineteenth century readily acknowledge the economic role of nomadic and semi-nomadic tribes, many studies on the nineteenth century focus instead on the negative impacts tribes are said to have had on settled communities, and they typically consider nomadic groups to be agents of economic destruction living off raiding villages and disrupting production. ${ }^{9}$ Anthropological studies focusing on the economic activities of nomadic tribes have challenged this understanding, ${ }^{10}$ and there are several studies arguing for the crucial economic functions that nomads performed in the nineteenth century. Sarah D. Shields, for example, has shown that the growing importance of animal products such as meat and wool gave a prominent role to nomads in nineteenth-century Mosul. In a similar vein, Tolga Cora has shown the growing importance of nomads in the local economy when animal trade to Damascus and other cities expanded significantly in the nineteenth-century province of Erzurum. ${ }^{11}$ Nora Elizabeth Barakat has analyzed the role of nomads in controlling lands and livestock by participating in the state administrative system in Al-Salt and Syria during the Hamidian era. ${ }^{12}$

7 Kasaba, A Moveable Empire, 22.

8 Samira Haj, "The Problems of Tribalism: The Case of Nineteenth-Century Iraqi History," Social History 16, no. 1 (1991), 48.

9 For a discussion and critique of this approach, see Sarah D. Shields, "Sheep, Nomads and Merchants in Nineteenth-Century Mosul: Creating Transformations in an Ottoman Society," Journal of Social History 25, no. 4 (1992), 774-776.

10 For example, see Richard Tapper, Pasture and Politics: Economics, Conflict and Ritual among Shahsevan Nomads of Northwestern Iran (London: Academic Press, 1979); Fredrik Barth, Nomads of South Persia: The Basseri Tribe of the Khamseh Confederacy (Boston: Little, Brown and Company, 1961); and Lois Beck, The Qashqa'i of Iran (New Haven: Yale University Press, 1974).

11 Yaşar Tolga Cora, "Transforming Erzurum/Karın: The Social and Economic History of a Multi-ethnic Ottoman City in the Nineteenth Century" (Ph.D. dissertation, University of Chicago, 2016).

12 Nora Elizabeth Barakat, "An Empty Land? Nomads and Property Administration in Hamidian Syria" (Ph.D. dissertation, University of California at Berkeley, 2015). 
The mobility of tribes played a crucial role in populating Anatolia and the Balkans, especially during the earlier centuries of Ottoman state formation. ${ }^{13}$ Even after the Ottomans had consolidated their rule in Anatolia, tribes remained economically significant for stock farming, hunting, tanning, and transportation. ${ }^{14}$ The livestock (mostly sheep, goats, cattle, and horses) not only supplied local needs, but was also consumed on an empire-wide scale. The meat supply of İstanbul was maintained mostly by the Rumelian provinces, ${ }^{15}$ and thus the contribution of Anatolian tribes has not been much acknowledged in the literature. However, as early as 1578 , the Ulus tribe, a part of the Yeniil confederation, was ordered to bring their sheep to İstanbul to fill the demand in the city. ${ }^{16}$

In addition to stock farming, nomadic and semi-nomadic tribes also took an active part in local trade. They sold dairy products, hunted animals, made hand-woven carpets, and tanned goods in local markets. What is more, their horses and camels were used to transport metals from mines to main trade routes, and in times of war some tribes were used to transport food supplies (rice, bread, and similar staples) to the battlefront. In many other instances, the Ottoman state saw the tribes as a pool for military recruits, especially in times of need. ${ }^{17}$ These relations with state authorities included both cooperation and conflict. Tribes benefited from the state funds gained through transportation and trade, but they mostly resisted demands of taxation and conscription. The state archives are in fact full of orders demonstrating the tribes' resistance concerning these two issues. ${ }^{18}$

The fluidity and dynamism of this earlier period of Ottoman state formation in terms of incorporating and cooperating with tribal groups was constrained in the seventeenth century as the result of several changing conditions. Imperial rivalry with the Habsburgs, Russians, and Safavids led to warfare on multiple fronts, and combined with a financial and social crisis this resulted in the Ottoman state having to focus more on regulating its internal

13 Ömer Lütfü Barkan, "Osmanlı İmparatorluğunda Bir İskan ve Kolonizasyon Metodu Olarak Sürgünler," Iktisat Fakültesi Mecmuası XI (1951); XIII (1953); XV (1955).

14 Orhonlu, Osmanlı Imparatorluğunda Aşiretlerin Iskânı, 21-23.

15 Ahmet Uzun, İstanbul'un Iaşesinde Devletin Rolü: Ondalık Ağnam Uygulaması 1783-1857 (Ankara: Türk Tarih Kurumu, 2006), 20.

16 Ahmet Refik (Altınay), Anadolu'da Türk Aşiretleri (966-1200) (İstanbul: Enderun, 1989), 32-33. Ahmet Refik mentions that the Yeniil confederation lived around Arapkir, Divriği, Çorum, Amasya, and Sivas in the summer and migrated to Damascus in the winter.

17 Orhonlu, Osmanlı Imparatorluğunda Aşiretlerin İskânı, 26-28.

18 For a collection of state orders about tribes before the nineteenth century, see Ahmet Refik, Anadolu'da Türk Aşiretleri. 
administration. The need to extract more revenue led to a stricter policy toward tribes, who were frequently forced into settlement in the seventeenth century. Indeed, from this time on, the Ottoman state made increasing attempts to sedentarize tribes and control their mobility.

Earlier attempts at settlement had not been particularly successful owing to the absence of adequate state resources. In fact, they resulted in the formation of large tribal confederacies that challenged the imperial center. ${ }^{19}$ With the Tanzimat reforms in the nineteenth century, the Ottoman state began its most systematic attempts to sedentarize many tribes in diverse regions of the empire, ranging from Bosnia across Syria to Transjordan. ${ }^{20}$ This was in line with the general idea of the reforms, which aimed to form a strong central state so as to better extract revenue and control population movements. The Tanzimat pattern of sedentarization, which involved a forced abandonment of movement and pastoral nomadism, was altogether different from earlier practices of settlement, which had attempted to pacify and control tribes without directly intervening in their internal administration. During the Tanzimat, the settlement policies eliminated migration routes and attempted to register the property and population of tribes for taxation purposes. The centralizing Ottoman state needed new finances, and sedentarization was expected to increase agricultural production, taxation revenue, and military conscription. In addition, the security of the peasantry and the opening of new lands for cultivation through tribal settlement was expected to contribute to the socioeconomic development of the Anatolian countryside.

Despite such expectations, however, sedentarization also had the potential to negatively affect animal trade and reduce the supply of meat to the imperial capital, as eliminating migration to pastures alongside sedentarization might impede herding and animal husbandry. Therefore, the Ottoman state had to adopt a number of flexible practices, such as allowing certain tribe members, especially those who were more obedient and less troublesome, to use the pastures closer to their new settlements from time to time.

19 A confederation was a large tribal unit made by gathering several smaller tribes, usually called boy, under the administration of one larger tribe; such confederations were usually called il or ulus. See Orhonlu, Osmanlı Imparatorluğunda Aşiretlerin İskânı, 14-21.

20 On Bosnia, see Ahmed Cevdet, Mar'ûzât; on Syria, see Birgit Schaebler, "State(s) Power and the Druzes: Integration and the Struggle for Social Control (1838-1949)," in The Syrian Land: Processes of Integration and Fragmentation, ed. Thomas Philipp and Birgit Schaebler (Berlin: Franz Steiner, 1998), 331-365; on Transjordan, see Eugene L. Rogan, Frontiers of the State in the Late Ottoman Empire: Transjordan, 1850-1921 (Cambridge: Cambridge University Press, 1999). 
This flexibility, however, created problems when tribes insisted on taking their animals to pastures that were better but more distant. ${ }^{21}$

With the Treaty of Baltalimanı of 1838, the Ottoman state adopted free trade policies and abandoned provisionist ones. ${ }^{22}$ Together with the Land Code of 1858, which legalized private property, and the adoption of commercial codes from Europe, these are all examples of the expansion of liberal policies. However, this was a gradual process in which the provisioning of İstanbul still concerned the state authorities. As a result, provisionist policies aimed at ensuring an adequate supply of meat remained in force until 1857.

The Cihanbeyli tribe was caught between two processes of the Tanzimat: centralization through settlement, and the continuation of meat provisioning during the adoption of liberal economic policies. As such, the tribe represents a significant case for an examination of how these dual processes influenced tribal organization and the economic role of tribes. Throughout the early phase of the Tanzimat, specifically from the 1840s to the 1860s, the Ottoman state attempted to settle the Cihanbeyli around the provinces of Konya and Sivas. During the same period, the Ottoman state was still struggling to maintain an adequate meat supply to the imperial capital and, thus, to keep meat prices relatively low for consumers. The new liberal policies meant minimal state intervention into the meat market, but even so, the state could not afford to allow discontent due to high prices spreading in the capital. As our findings discussed below will show, when the meat supply from Rumelia dropped as a result of territorial losses and warfare, it was the Anatolian tribes, and mainly the Cihanbeyli, who emerged as İstanbul's meat supplier. It is important to note in this context that the Cihanbeyli was estimated to provide 6.6 to 20 percent of the capital's meat supply, meaning that the majority of the animals in İstanbul were still brought there from Rumelia. ${ }^{23}$ Some other Anatolian regions-such as Erzurum, Konya, and Karaman-supplied animals to the capital as well. In fact, the sheep coming from these regions passed through areas controlled by the

21 Yonca Köksal, "Coercion and Mediation: Centralization and Sedentarization of Tribes in the Ottoman Empire," Middle Eastern Studies 42, no. 3 (2006): 477-478.

22 The Treaty of Baltalimanı ended state monopolies and reduced customs duties and taxes to British merchants, thereby providing them with a competitive advantage in the Ottoman market. With the expansion of these privileges to other European merchants, both imports and exports were encouraged, creating a contrast to earlier provisionist policies, which sought to exercise some state control over markets and prices in order to provide food to cities. See Şevket Pamuk, The Ottoman Empire and European Capitalism, 1820-1913: Trade, Investment, and Production (Cambridge: Cambridge University Press, 1987).

23 In the early nineteenth century, it was still Rumelia that provided the major source of meat and the ondalık ağnamı tax. More than 2,000 people were employed in the ondalık ağnamı tax collection network of the Chalikov family, the major cattle traders (celep) of Bulgaria. See Andreas Lyberatos, "Men of the Sultan: The Beglik Sheep Tax Collection System and the Rise of a Bulgarian National Bourgeoisie in Nineteenth-century Plovdiv," Turkish Historical Review 1 (2010): 55-85. 
Cihanbeyli on their way to İstanbul, and the sheep drovers had been registering frequent complaints about their security en route since the late eighteenth century. ${ }^{24}$ Although the settlement of the Cihanbeyli tribe had the potential to adversely impact the meat supply, the advantages of settlement-centralization, taxation, conscription, and agricultural productionas well as security of passage along animal trade routes must also have been important concerns behind the state's settlement decision. On the other hand, settlement did not necessarily mean the end of animal husbandry, as archival documents show that the Cihanbeyli continued to engage in animal trade from their villages to İstanbul even in the 1880 s. $^{25}$

There were different layers to this trade, in which tribal leaders, moneylenders, foreign merchants, and state authorities all cooperated and sometimes conflicted with each other. The settlement attempts and liberal policies created a major challenge to this meat trade and its network, both for the Cihanbeyli tribe and for the Ottoman state authorities. The case of the Cihanbeyli thus constitutes a good example for closely examining the economic significance of tribes during a period of sedentarization and the continuation of meat provisioning under a liberalizing economy.

\section{The meat provisioning of Istanbul}

Ahmet Uzun has noted the constant increase in the demand for mutton from the Cihanbeyli tribe, which occurred as the Rumelian sheep supply decreased throughout the late eighteenth and nineteenth centuries. In 1800, the Cihanbeyli were required to send 80,000 sheep, a number that increased to 100,000 in 1835 and to 120,000 in the 1840 s. ${ }^{26}$ Estimates for the total meat consumption of İstanbul range widely, between 600,000 and 1,800,000 sheep for the early nineteenth century. ${ }^{27}$ Thus, as mentioned above, the Cihanbeyli tribe itself was required to maintain a minimum of 6.6 percent and a maximum of 20 percent of the meat supply of the capital. To understand how the

24 See the Ottoman Archives of the Republic of Turkey's Presidential State Archives (Türkiye Cumhuriyeti Cumhurbaşkanlığı, Devlet Arşivleri Başkanlığı, Osmanlı Arşivleri; hereafter BOA) AE.SSLM III 254/14704 Zilhicce 29, 1206 (August 18, 1792).

25 There was a chief sheep trader of the Cihanbeyli resident in İstanbul who organized the animal trade from the Cihanbeyli villages until the abolition of the title of chief sheep trader in 1883. See BOA: Y.PRK.AZJ 6/103, Cemaziyelahir 11, 1300 (April 19, 1883).

26 Uzun, istanbul'un laşesinde, 21. Archival documents show that this number was already at 100,000 in 1827. See BOA: C.BLD 140/6963, Muharrem 29, 1243 (August 22, 1827). Also see BOA: C.BLD 37/1836, Safer 14, 1265 (January 21, 1848).

27 Anthony Greenwood, "İstanbul's Meat Provisioning: A Study of the Celepkeşan System" (Ph.D. dissertation, University of Chicago, 1988), 19. 
Cihanbeyli emerged as an important actor in this trade, though, we need to first explain how the meat provisioning system worked in the Ottoman Empire.

Whether or not the Ottoman Empire had a state-controlled economy has been a topic of considerable debate among historians. Şevket Pamuk has argued that, instead of a strictly controlled economy, over time the Ottoman state adopted selective interventionism as a general policy, intervening when considered necessary (e.g., in times of crisis or immediate state need) but otherwise leaving the market forces and the state to negotiate and decide. ${ }^{28}$ Istanbul's meat provisioning can serve as an example of this selective interventionism. From the sixteenth century onward, the Ottoman state strictly controlled the meat provisioning of the palace, as well as of military and civilian officials in İstanbul, while restricting itself to minimal intervention and leaving market forces relatively free as far as concerned the meat supply of the city's ordinary residents.

To provide for the needs of the palace and its officials, the celepkeşan system was employed in the sixteenth century. This system was based on the appointment of wealthy people in the Rumelian provinces to serve as celepkeşan (sheep dealers) providing a certain number of sheep to İstanbul. The celepkeşan were responsible for buying and transporting the required number of sheep from their localities to the capital. They made little profit from this business, and in fact it was mostly wealthy people who had acquired their fortunes by illegitimate means who were registered as celepkeşan, effectively making it as a kind of punishment, and this in turn became a kind of avariz, originally an emergency tax in kind that over time turned into a regular tax. ${ }^{29}$

The main idea behind this earlier system was to keep the price of meat low so that the palace, soldiers, and officials received sufficient meat at a low cost to the state treasury. The transportation of sheep from Rumelia to İstanbul was facilitated by granting exemptions from pasture taxes. For the provisioning of İstanbul's ordinary population, there existed no strict regulation, but the state did employ a few measures to ensure that there would be an adequate meat supply at reasonable prices. For example, there were attempts to keep the prices of sheep lower in the Rumelian provinces than in İstanbul so that merchants and producers would prefer to bring their sheep to the capital for sale. ${ }^{30}$

This system worked well as long as prices were stable, which was the case until the 1590s. However, with rising inflation toward the end of the sixteenth century, it became very difficult to manage the celepkeşan system, which was based on a neat balance between keeping prices as low as possible while also leaving a minimum profit margin for the producers (so that they would bear

28 Şevket Pamuk, "Institutional Change and the Longevity of the Ottoman Empire, 1500-1800," Journal of Interdisciplinary History 35 (2004): 225-247.

29 Greenwood, "İstanbul's Meat Provisioning," 62-155.

30 Ibid., 55-57. 
the cost of raising stock). As a result of the changing situation, the celepkeşan ultimately began to fail to bring the required number of sheep to İstanbul. As an alternative, in the seventeenth century the Ottoman state opted to take more control over the system. Now, instead of collecting sheep directly, the state switched to collecting a fee (bedel), the cash value of which was equal to the number of required sheep. ${ }^{31}$ The amount of the bedel was distributed among all producers. Once the celepkeşan system had partially turned into a cash tax, it then immediately became part of the tax farming (iltizam). Instead of several celepkeşan being forced to collect sheep, a few of them who were tax farmers (mültezim) became responsible for collecting this new tax in either cash or kind. This tax provided adequate means for the state authorities to organize the collection and transportation of sheep from Rumelia to İstanbul. This system continued until 1793, when a new tax, the ondalık ağnamı ("one-in-ten sheep [tax]") was introduced in Rumelia, with the only difference from prior practice being that the amount of taxation was regulated, so that now the tax would be one out of every ten sheep, whether in cash or kind.

The practices of celepkeşan, iltizam, and ondalik ağnamı were applied in Rumelia, the major source for the meat provisioning of the imperial capital. Parts of Rumelia offered fertile ground for stock raising, and the region's proximity to İstanbul made the transportation of sheep easy. It was mainly in times of extreme need, such as military campaigns and famines, that the Ottoman state began to look toward Anatolian stock. This usually took the form of efforts being made to force Anatolian producers to direct their stocks to İstanbul. Sometimes, special agents were sent to physically accompany these flocks to the capital, and the number of sheep as well as of those individuals who promised to deliver them began to be registered as early as the late sixteenth century. ${ }^{32}$ The exact number of Anatolian sheep sent to İstanbul was not well documented, but it is certain that the demand for Anatolian sheep increased over time in tandem with the rise of İstanbul's population, a greater frequency of warfare, and the gradual loss of Rumelian territories. In 1730, to give one example, 100,000 sheep were ordered to be sent to İstanbul from Erzurum, with 40,000 being ordered from Karaman, Ankara, and Kırşehri. ${ }^{33}$

While the ondalık ağnamı was in effect in Rumelia, a similar tax called the bedel-i ağnam was applied in Anatolia. ${ }^{34}$ Like the ondalı ağnamı, the bedel-i ağnam was taken from the producers and calculated based on the number of animals required to be sent to Istanbul. In addition to these taxes, the

31 Not all kinds of bedel were collected in cash; some were still taken in kind.

32 Greenwood, "Istanbul's Meat Provisioning," 28.

33 Ibid., 30.

34 Ahmet Uzun has claimed that the authorities tried the ondalık ağnamı in Anatolia, but turned it into the bedel-I ağnam after only a short while. See Uzun, İstanbul'un İaşesinde, 52-55. 
Ottoman state collected various other animal taxes, such as the adet-i ağnam (total animal tax) and the otlak or yaylak kışlak resmi (pasture tax) in Rumelia and Anatolia. Among these various taxes, it was the ondalik ağnam and the bedel-i ağnam that were specifically collected for provisioning the meat supply of İstanbul. Then, in 1857, the ondalı ağnamı was abolished and the various animal taxes were reduced to a single sheep (ăgnam) tax imposed first in Rumelia and, a year later, in Anatolia. Various complaints about overtaxation and about tax farmers usurping the best sheep may have played a role in this change. In addition, a change in the mindset of state officials may also have had an important role: the ondalik ağnamı - whether taken in cash or, especially, in kind - meant taking away from the primary capital of producers, and this was against the idea of taxing the income but not the capital, which was the main motto of the Ottoman state's new taxation policy. ${ }^{35}$ The simplification of a diversity of animal taxes into a single one was also assumed to decrease workload and thus the need for officials, thereby reducing state expenses.

The ondalik agnam and the bedel-i agnam provided the main resource for the meat provisioning of the palace and state officials, and so their elimination meant a radical change in provisioning policies. Provisioning for the palace and the military continued, but the Ottoman state now decided to cease providing meat to civil officials. In place of this, a calculated amount was to be added to these officials' salaries. The meat supply of the palace and the army, on the other hand, would be maintained by collection of the new single sheep tax. As for İstanbul's ordinary residents, while the Ottoman state never had complete control and regulation over the meat market for them, it did always take certain measures to keep meat prices low in general. However, with the aforementioned simplification of the animal tax system, İstanbul residents became vulnerable to fluctuations in meat prices. ${ }^{36}$ The following section will discuss how these changes in meat provisioning influenced the Cihanbeyli tribe's role in animal trade.

\section{The Cihanbeyli tribe and sheep trading}

The earliest document concerning the Cihanbeyli tribe mentions the unrest it caused in the districts of Ankara and Aksaray in $1577 .{ }^{37}$ In 1766, they were reported as residing mainly in the provinces of Diyarbekir and Musul and in the district of Mardin, with 100,000 tents. They frequently deserted their settlements and moved to create unrest in Ankara and the neighboring provinces.

35 Stanford J. Shaw, "The Nineteenth-Century Ottoman Tax Reforms and Revenue System," International Journal of Middle East Studies 6, no. 4 (1975): 421-459.

36 Uzun, Istanbul'un laşesinde, 116.

37 Ahmet Refik, Anadolu'da Türk Aşiretleri, 54. 
By the beginning of the Tanzimat era in the mid-nineteenth century, the Cihanbeyli tribe was geographically quite scattered and mobile. In the district of Sivas, 600 Cihanbeyli households were recorded.$^{38}$ In his 1908 monograph on the Kurdish tribes of the Ottoman Empire, Mark Sykes reported that the Koçgiri tribe consisted of 10,000 families in the little-known district north of the Sivas-Zara road. ${ }^{39} \mathrm{He}$ also described the Janbekli (i.e., Cihanbeyli) tribe of 5,000 families near Ankara, noting that this tribe was probably the remnants of the Raqqa exile. ${ }^{40}$

One Tanzimat strategy for settlement was to declare a tribe a separate administrative unit (müstakil mubassillik) and to then bring smaller tribes and tribal sections under its administration, thereby forming a structure similar to a confederation. Even before the Tanzimat, though, by as early as 1802 the Cihanbeyli tribal chief was already responsible for organizing the animal trade from six smaller tribes under his authority. ${ }^{41}$ The Ottoman state would appoint a local bureaucrat or notable as the governor (kaymakam), who would take orders for settlement directly from the state. This was a strategy to reduce the power of tribal chiefs. During the Tanzimat, the Ottoman state managed to reduce the power of the strong Cihanbeyli chief by imposing local and tribal section headmen and distributing administrative duties among them. The most influential tribal chief of the Cihanbeyli tribe was Alişan Bey, who ruled the tribe for ten years (1842-1852) and was an indispensable part of the Tanzimat administration. During the period when the Cihanbeyli were separately administered, Alişan Bey ruled alongside the governor of the tribe. The appointed Cihanbeyli governor depended on Alişan Bey's support, as the former was an outsider and had little knowledge of tribal relations. Though Alişan Bey was never appointed as governor of the tribe, his officially granted title of mir (chieftain) demonstrates the state's acknowledgement of

38 BOA: Ayniyat Defteri 399, p. 81, Cemaziyelevvel 28, 1262 (May 24, 1846).

39 Archival documents occasionally use the names "Koçgiri" and "Cihanbeyli" interchangeably. This is probably because of the small number of Cihanbeyli living closely with the Koçgiri. Sykes describes the Koçgiri as "a peculiar nation, or perhaps one might call them a separate nation"; see Mark Sykes, "The Kurdish Tribes of the Ottoman Empire," The Journal of the Royal Anthropological Institute of Great Britain and Ireland 38 (1908), 479. Mamo Baran mentions that the Koçgiri and the Cihanbeyli (Canbegan) were two separate tribes in the district of Koçgiri; see Mamo Baran, Koçgiri: KuzeyBatı Dersim (İstanbul: Tohum, 2002), 51-54. See also Köksal, "Coercion and Mediation," 476, 481.

40 Sykes, "The Kurdish Tribes," 472, 481-482. From the seventeenth century, tribes that were considered rebellious were usually sent to exile in Raqqa in Syria. Raqqa was inhabited by semi-nomadic Arab tribes, and Kurdish and Turcoman tribes tended to escape the exile and return to their lands in Anatolia after a short while. See Orhonlu, Osmanlı Imparatorluğunda Aşiret İskanları, 57-65.

41 These tribes were the Seyfhanlı, Atmanlı, Şeyh Bezenli, Zeyveli, Mikailli, and Kikelli. See BOA: C.BLD 151/7522, Zilkade 29, 1216 (April 2, 1802). 
his power. ${ }^{42} \mathrm{He}$ was willing to cooperate with the state, since this provided him with benefits, such as the ability to collect taxes and to have an entourage of state troops. ${ }^{43}$

As discussed in the previous section, the Cihanbeyli tribe had been involved in sheep trade since the late eighteenth century. In the 1840s, the Cihanbeyli involvement in large-scale sheep trading operations increased, and the tribe began to provide a considerable proportion of İstanbul's meat supply. These operations were carried out via a vast trade network extending from central Anatolia westward to İstanbul, Bursa, İzmir, and İzmit. Sheep raised by the members of the tribe, as well as sheep collected from other tribes, were transported to and sold in these centers. In the 1840s, the tribe provided 120,000 sheep to İstanbul annually. The sheep brought to the capital were sold according to the current value (rayiç bedeli) of sheep in the city by Ahmet Agha, the tribe's chief sheep trader, who resided in İstanbul. ${ }^{44} \mathrm{He}$ was responsible for selling the sheep to the city's butchers and for managing the execution of the trade agreement that existed between the tribe and the Sublime Porte. This sheep trade providing meat for the capital was the main business of the Cihanbeyli, and was carried out on the basis of this agreement, which granted several privileges to the tribe: in addition to a number of tax exemptions, the Cihanbeyli were also given the right to free passage through the area between Ankara and İstanbul, which meant that they did not have to pay for the usual passage permits. ${ }^{45}$

The transportation of sheep from central Anatolia to İstanbul entailed several difficulties. According to George Perrot, who visited the Haymana region of Ankara and its environs, the journey from Ankara to İstanbul took about forty days. During these long trips, sheep traders would encounter several security risks, including livestock theft by neighboring tribes or brigands. Moreover, the region's transportation infrastructure was underdeveloped. Due to a lack of bridges, the tribes faced difficulties in crossing the Kizllirmak, the region's largest river, and in the winter months transportation across the Kizilirmak became impossible, which hindered commerce. In 1861, the government decided to build a wooden bridge across the river. The burden

42 Köksal, "Coercion and Mediation," 481-482.

43 Alişan Bey's title was recorded as istabl-ı amire, a title that was granted to successful state officials. BOA: Ayniyat Defteri 418, p. 109, Zilkade 1, 1266 (September 8, 1850).

44 BOA: C.BLD 37/1836, Safer 14, 1265 (January 21, 1848) and BOA: A.M 4/41, Zilhicce 9, 1262 (November 18, 1847).

45 The Ottoman state granted a trade privilege (berat) to the Cihanbeyli tribal chief and appointed him as the chief trader (tacirbaşı) in the 1810s. The tribal chief was responsible for the collection and transportation of sheep from eight tribes in the Cihanbeyli confederation. Although the original document recording this was burned in a fire, it was mentioned in a petition written by members of the Cihanbeyli in 1883. BOA: Y.PRK.AZJ 6/103, Cemaziyelahir 11, 1300 (April 19, 1883). 
of providing funds for this bridge, which was to be built near Kalecik, was shared between the government, which gave 25,000 piasters (kurus), and a Kurdish cattle merchant who provided 35,000 piasters. ${ }^{46}$ This example indicates that individual merchants in the region were not only involved in large-scale trading operations, but also contributed to the improvement of the transportation infrastructure that would facilitate their trade.

Raising, collecting, and transporting sheep at such volume was a costly matter for the tribes involved. Moreover, these and other tribal expenditures required cash, which could only be received after the finalization of sales. For this reason, tribes and cattle merchants often applied for credit from moneylenders, and in the 1840s the Cihanbeyli tribes sought to receive credit from a number of moneylenders. ${ }^{47}$ One of these was David Savalan, a Russian subject. Though the available sources offer little information about Savalan, they clearly reveal that he conducted extensive moneylending and trade operations from the Balkans to Anatolia. For example, he was involved in leech fishing in the districts of Vidin and Silistre in the Balkan region, holding an imperial order dating to 1848 that allowed him to conduct such trade. ${ }^{48}$ Additionally, he, along with a man named Abraham Theodorides, was granted a mining concession in the Karahisar district of the province of Sivas. ${ }^{49}$ In 1873, Theodorides sold his share to Savalan, whose concession was then renewed for 99 years. ${ }^{50}$ Savalan also owned several farms in Manisa and İstanbul. ${ }^{51}$

In the early 1840s, Savalan gave a credit of 2,100,000 piasters (approximately 19,000 British pounds) to the Cihanbeyli tribe. ${ }^{52}$ The fact that the Cihanbeyli were granted such a large credit undermines the presumption that nomadic and semi-nomadic tribes were impediments to trade and economic activities in the nineteenth century. On the contrary, the amount of the credit

46 Georges Perrot, "Les Kurdes de I'Haimaneh," Revue des Deux Mondes (February 1865): 607-631.

47 Alişan Bey, the chief of the Cihanbeyli, received credit worth 30,174 piasters from the moneylender Artin Tankıroğlu. See BOA: A.MKT 107/46, Safer 4, 1264 (January 11, 1848). Three merchants from the Cihanbeyli also received about 40,000 piasters from the Russian moneylender Giovanni Delta. See BOA: HR.MKT 49/15, Zilkade 19, 1268 (September 4, 1852). Another example of this was when the moneylender Nishan gave Rauf Bey, the governor of the Cihanbeyli tribe, credit worth 24,403 piasters. See BOA: A.MKT.UM 286/71, Zilkade 6, 1273 (June 28, 1857).

48 BOA: A.MKT 182/6, Rebiülahir 22, 1265 (March 17, 1849).

49 BOA: ŞD 256/11, Cemaziyelahir 5, 1290 (July 31, 1873). See also "Report by Consul Biliotti on the Silver Lead Mines near Karahissar," in Commercial No. 4 (1884) (Trade Reports) (London, 1884): 150-155.

50 BOA: I.MMS 65/3063, Muharrem 1, 1297 (December 15, 1879). For detailed information about the Licese mine in the district of Karahisar, see Kemal Saylan, "Licese Maden Ocağı ve Asia Minor Mining Company'nin Licese'deki Faaliyetleri," Tarih Incelemeleri Dergisi XXIX, no. 2 (2014): 625-643.

51 BOA: A.MKT.UM 286/39, Şevval 5, 1271 (June 21, 1855) and BOA: BEO 2937/220238, Teşrin-i Evvel 16, 1322 (October 29, 1906).

52 BOA: I.MSM 26/748, Şaban 27, 1263 (August 10, 1847). 
and its international character indicates that the Cihanbeyli was in fact an active economic actor involved in large-scale monetary deals. Although the documents pertaining to this matter do not state the reason for the granting of the credit, it is reasonable to assume that it was for the tribe's expenses for the collection, raising, and transportation of sheep. While the debt was taken on by Alişan Bey, the tribal chief, the fact that the leaders of the tribes that made up the confederation acknowledged their share in the debt and gave assurances for its payment highlights the debt's collective character and supports the claim that it was taken for the sheep trade of the tribal confederation, rather than for Alişan Bey's own individual expenses.

In the mid-1840s, the non-payment of this debt led to the emergence of a multilayered crisis among the Russian consulate, the Ottoman government, local authorities, the tribes that formed the Cihanbeyli confederation, and sheep traders from different backgrounds. As a Russian subject, Savalan requested the assistance of the Russian consulate to collect the debt owed to him, and in line with this request the consulate, via the submission of a series of memoranda, pressured the Ottoman government to take the necessary measures to collect this debt. ${ }^{53}$ These diplomatic efforts on the part of the Russians put considerable pressure on the Ottoman government. However, the primary concern of the Ottoman authorities in İstanbul was the maintenance of the capital's meat supply. As noted in the relevant decision by the Council of Judicial Ordinances (Meclis-i Abkâm-ı Adliye, MAA), although Savalan's complaints could not be set aside, it was nevertheless of the utmost importance to prevent the harm that would be caused by disrupting the supply of meat to İstanbul. According to the MAA, the distress and hardship that would be encountered by the inhabitants of İstanbul in such a situation "was not something acceptable" (tecviz olunur mevaddan olmadiğı)..$^{54}$

In 1846, the non-payment of the debt erupted into a crisis that threatened İstanbul's meat supply when, in İstanbul, Savalan confiscated the transaction values of sheep (ağnam yaftast) belonging to the Zeyveli tribe, which was a part of the Cihanbeyli confederation. ${ }^{55}$ It was only with this event that the Ottoman government became involved in the matter, as Savalan had been insistently requesting it to do. On August 10, 1847, the MAA discussed the issue and negotiated between the parties. This meeting was attended by those members of the tribe who were present in İstanbul at the time, Savalan, and the undersecretary (müsteşar) of the Russian consulate, Hançerli Bey. In this meeting, Savalan agreed to receive 500,000 piasters fewer than what he was

53 BOA: A.MKT 62/90, Muharrem 26, 1263 (January 14, 1847).

54 BOA: I.MSM 26/748, Recep 12, 1264 (June 14, 1848).

55 BOA: A.MKT 62/35, Muharrem 11, 1263 (December 30, 1846). 
actually owed, after which reduction the total sum due to Savalan was determined to total 972,000 piasters. This debt was distributed among the eight tribes of the Cihanbeyli confederation. The parties agreed on the collection of this sum in two installments, with the Zeyveli tribe assuming guarantorship. In the decision regarding this agreement, it was stipulated that, in case the installments were not paid on time, the transaction values of the sheep sold by the tribes to İstanbul and other places would be confiscated and delivered to Savalan. Furthermore, the Ottoman government would appoint an agent (mübaşir) to see to the collection of the debt. At the meeting, the tribe's leaders were also asked about their level of satisfaction with Alişan Bey's leadership, and all of them expressed that they were content. ${ }^{56}$ Following the MAA's decision, the Sublime Porte continued its attempts to facilitate the tribes' sheep trade, and it sent out orders concerning the promotion of this trade and the protection of tribal members from any abuses related to the collection of debts.

Despite the recognition of the debt's collective character at the MAA meeting, some tribes tried to avoid the burden of payment. For example, the Devikanl tribe objected to paying its share of 108,000 piasters, arguing that they were living in Karahisar, and similarly the Şeyhbiganl tribe argued that, as inhabitants of Eskişehir, they should be exempted from their share of 52,500 piasters. It is not clear exactly why the tribes claimed exemption from the debt on the basis of their being inhabitants of other areas, but in doing so, they were emphasizing that they were living in areas beyond the region that was under the control of the Cihanbeyli. This emphasis might have been a means of legitimizing their demand for exemption. In any case, however, the Sublime Porte decided that such exemptions would lead to injustice inasmuch as they would increase the burden of debt on the remaining tribes. As a result, the district governors were ordered to collect the sums to be paid by these two tribes. ${ }^{57}$

According to the MAA's decision, the tribes had to finalize the payment of the first installment by November 19, 1847. However, they failed to make this payment on time, and as a result the sheep that the tribes transported to İstanbul and other places began to be confiscated. Evaluating this process, Hüseyin Hüsam, the director of the sheep tax (ağnam müdürü), underscored how this process of confiscation led to a number of problems and difficulties. ${ }^{58}$ He argued that some of the sheep transported by the tribes had not actually

56 BOA: İ.MSM 26/748, Şaban 27, 1263 (August 10, 1847).

57 BOA: A.MKT 102/78, Zilhicce 20, 1263 (November 29, 1847).

58 Confiscating the animals of nomads in lieu of unpaid taxes to the state appears to have been a common practice in the nineteenth century. For instance, nomads sued treasury officials in the Sharia courts of Al-Salt for confiscating their horses and other animals; see Nora Barakat, "Marginal Actors? The Role of Bedouin in Ottoman Administration of Animals as Property in the District of Salt, 1870-1912," Journal of the Economic and Social History of the Orient 58 (2015), 128. 
been raised by the tribes themselves, but rather had been collected from various sheep farmers whom the tribe's traders had promised to pay once the animals had been sold. Hüseyin Hüsam also noted that several traders were complaining that the value of the sheep confiscated from them exceeded their share of the debt. It was for such reasons as these that the tribes' sheep traders had decided not to transport sheep to İstanbul. Emphasizing the risks of this for the meat supply of İstanbul, Hüseyin Hüsam proposed a new method for the collection of the second installment of the debt. The remaining part of the first installment would be collected at the local level on a cash basis. If the tribes wished to pay the second installment not in cash but in kind, then the sheep they delivered would be sold to sheep dealers sent from İstanbul, in line with the current local value (rayiç bedeli) of sheep, and transported to İstanbul by these sheep dealers rather than by the tribesmen. ${ }^{59}$ This proposal was approved by the MAA on April 10, 1848, and a certain Cemal Efendi was appointed to execute this plan. ${ }^{60}$

Upon delay of the first installment, local authorities had begun to confiscate sheep and rugs, as well as cash, from the Cihanbeyli tribes. According to Hüseyin Hüsam, the sheep and rugs were sold at auction, but Savalan complained that the sums of these sales were held in the local coffers (mal sandiğt) at Ankara, rather than being delivered to him. ${ }^{61}$ For this reason, both Savalan and the Russian consulate continued to submit petitions and memoranda to the Sublime Porte. On May 3, 1848, Cemal Efendi reported that the non-payment of the debt was the outcome of the Cihanbeyli chief Alişan Bey's incompetence and inappropriate qualifications for his position. He noted that Alişan Bey had sent 2,500 sheep and twenty rugs as the first payment; however, since the sheep sent by Alişan Bey were in poor condition (çürük), they were worthless (değersiz). ${ }^{62}$ The sum of the confiscated transaction values and the sums derived from the sale of sheep and rugs amounted to 583,000 piasters- 57,000 piasters short of the first installment. Cemal Efendi noted that, in order to collect the debt, the district governor (mutasarrif) had sent a constabulary (zabita) to the bridge at İstanoz, which the tribe would use in their journey to the summer pasture. He also elaborated on Hüseyin Hüsam's original proposal for the collection of the second installment in kind, via the use of celepkeşan. In his view, the tribes could of course give sheep for this installment, but these sheep would likely be as weak and worthless as those provided for the first payment, and so they would have

59 BOA: A.MKT 116/56, Rebiülahir 19, 1264 (March 25, 1848).

60 BOA: A.MKT.MVL 8A/69, Cemaziyelevvel 6, 1264 (April 10, 1848).

61 BOA: I.MSM 26/748, undated.

62 The weight of Ottoman sheep ranged between 15 and 40 kilograms, which was significantly lower than the weight of sheep reared in the Netherlands, Germany, Belgium, and France, which ranged between 50 and 80 kilograms. See M. Erdem Kabadayı, "The Introduction of Merino Sheep Breeding in the Ottoman Empire: Successes and Failures," in Animals and People in the Ottoman Empire, ed. Suraiya Faroqhi (İstanbul: Eren, 2010): 153-169. 
to be grazed for eight months before being transported to İstanbul. He thus proposed collecting the debt from the Zeyveli tribe, the guarantor, underscoring how both the Cihanbeyli and the Zeyveli were Kurdish and could handle the debt among themselves via the transfer of sheep and rugs. Cemal Efendi also warned the Sublime Porte that the sheep trade from that region to İstanbul would decline in the upcoming months, since the tribes would not be sending great numbers of sheep to the capital owing to all these troubles. The Porte, according to Cemal Efendi, therefore had to find alternative suppliers to maintain the capital's meat supply. ${ }^{63}$

Although Cemal Efendi did not mention it in his telegram, the sheep's poor condition might have been related to a drought that broke out in 1845 and affected the entire region inhabited by the Cihanbeyli tribes. This drought and the subsequent famine caused the death of humans and animals, destroyed agricultural production, and encouraged emigration out of Ankara and surrounding regions. ${ }^{64}$ This natural disaster might well have damaged the tribe's grazing areas, making it difficult to provide sheep in good condition. Moreover, the drought and famine might also have led to the non-payment of the debt to Savalan, but neither the reports written by officials nor telegrams from the members of the tribe mentioned this as a reason for the tribe's failure to pay the debt.

The non-payment of the debt owed to Savalan began to undermine the leadership of Alişan Bey, as he was singled out as responsible for the eruption of the debt crisis that was now threatening the capital's meat supply. The problems with debt collection, and the accompanying property seizures and abuses, began to turn the tribes against Alişan Bey. On May 15, 1848, the district governor, the director of Ankara's financial administration (defterdar), Cemal Efendi, and Ruhi Efendi, the agent appointed by the Sublime Porte to collect the debt, all suggested that he be dismissed. They argued that the problems encountered in connection with the payment of the debt to Savalan, with tax collection, and with the maintenance of security in the region were all related to his incompetence. An important issue underscored in the telegram that was sent is that the leaders of tribes under the Cihanbeyli were also dissatisfied with Alişan Bey's leadership. Nevertheless, just a year before, when the debt issue had been negotiated at the Porte, those same leaders had expressed support for his leadership. ${ }^{65}$

This fact supports the argument that the repayment of the debt to Savalan and the problems encountered in this process served to undermine Alişan Bey's

63 BOA: I.MSM 26/748, Cemaziyelevvel 29, 1264 (May 3, 1848).

64 For detailed information on the 1845 drought and famine, see Mehmet Yavuz Erler, "Ankara ve Konya Vilayetlerinde Kuraklık ve Kıtlık (1845 ve 1875 Yılları)" (Ph.D. dissertation, Ondokuz Mayıs University, 1997), and Semih Çelik, "Scarcity and Misery at the Time of 'Abundance beyond Imagination': Climate Change, Famines and Empire-Building in Ottoman Anatolia (c. 1800-1850)" (Ph.D. dissertation, European University Institute, 2017).

65 BOA: I.MSM 26/748, Cemaziyelahir 11, 1264 (May 15, 1848). 
position as chieftain of the Cihanbeyli confederation. In a separate telegram sent to the Porte on May 17, 1848, Cemal Efendi stressed that the establishment of order in the region, which was the state's primary objective, would not be possible as long as Alişan Bey retained his position (astl istenilen mübim emniyet maddesinin dabi gerçekleşmesi). ${ }^{66}$ This telegram indicates that the orders given to Cemal Efendi were not in fact limited to the payment of the debt, but also included investigating the local situation in terms of the maintenance of public order.

The news that the sheep trade from the region to İstanbul would be hindered in the upcoming months particularly alarmed the Ottoman authorities. In his evaluation of the situation, Hüseyin Hüsam, the director of the sheep tax, noted that the city consumed 300,000 sheep on an annual basis. Of this number, 70,000 sheep that had been transported to İstanbul in line with the ondalık ağnamı would be used for provisioning the soldiers deployed to the city. As such, it was not possible to distribute these sheep to the butchers. The sheep traders from Rumelia would provide another 120,000 sheep, but the remaining 180,000 had to be supplied from Anatolia. There was, according to Hüseyin Hüsam, no other alternative. ${ }^{67}$

As it became clear that the debt crisis between Savalan and the Cihanbeyli tribes could potentially disturb the capital's meat supply, the MAA held another meeting regarding the issue on June 14,1848 . In this meeting, it was emphasized that the city's meat supply must not be put at risk, and that the problem therefore had to be resolved in such a way as to ensure this outcome. The estimations included in this decision highlight the central role played by the Cihanbeyli tribes in the capital's meat supply. As mentioned above, in 1848, 120,000 sheep would be provided by merchants in Rumelia, and Erzurum would send an additional 15,000 sheep. This meant that 165,000 sheep had to be provided from other places or by other means. As was emphasized in the MAA's decision, a portion of this shortage could be covered by the adoption of an extraordinary measure whereby a Rumelian merchant, Mehmed Bey, would supply some sheep to the capital, while another portion would be covered by sheep sent from Konya, İspekşan, and Çorum. However, it would be sheep sent from the areas of the Cihanbeyli tribes that would have to cover the majority of the shortage. With these concerns in mind, the MAA decided that the cases of the Cihanbeyli and Zeyveli tribes should be separated from the cases of the other tribes in the Cihanbeyli confederation. The sheep belonging to the former would be confiscated, whereas the latter would be spared confiscation and their involvement in sheep trade promoted. The treasury was ordered to assist these tribes in the collection of the sums that they would receive for the sale of sheep. The

66 BOA: I.MSM 26/748, Cemaziyelahir 13, 1264 (May 17, 1848).

67 BOA: I.MSM 26/748, Cemaziyelahir 19, 1264 (May 23, 1848). 
district governor of Ankara was given the authority to dismiss Alişan Bey. Thus, in line with Cemal Efendi's suggestion, the MAA decided to distribute the burden of paying the tribal debt between the Cihanbeyli and the Zeyveli, the latter of whom had served as guarantor. ${ }^{68}$

The measures taken in this meeting demonstrate that the Ottoman authorities were continuing to play an interventionist role with regard to the sheep market during this period. Since the meat supply to the capital was at risk, the Rumelian merchant Mehmed Bey was tasked with providing 15,000 sheep to the city's butchers on a monthly basis. Because Mehmed Bey was not willing to transport his sheep to the capital, where meat prices were low as compared to other urban centers, the meat prices in İstanbul would be raised for a period of four months between the beginning of December and the end of March-that is, the months estimated to have the highest risk in terms of the city's meat supply. In line with this decision, the price of meat to be sold to butchers was raised from 86 to 100 para per kiyye/okka, ${ }^{69}$ while the retail price would be 110 para per kiyye/okka. The authorities would punish any butchers who openly or secretly sold meat above this price by cutting them off from the supply chain. ${ }^{70}$

Following the decision, the state sent several orders to the local authorities in the regions where the Cihanbeyli and Zeyveli tribes sold their sheep. These orders underscored that the cases of these two tribes were to be separated from the affairs of the other tribes that made up the Cihanbeyli confederation, and that only the sheep transported by the former were to be confiscated for the collection of the debt owed to Savalan. For instance, the Sublime Porte informed the field marshal (müşir) of province of Hüdavendigar that the Cihanbeyli tribesmen had sold sheep to butchers in the districts of Bursa, Mihaliç, Gemlik, and Mudanya, and that the butchers owed them 55,480 piasters for these sales. The field marshal was ordered to collect this money and deliver it to Savalan. He was also informed that the Cihanbeyli tribe owned sheep that were being transported to the region at the moment of correspondence, and he was ordered to confiscate the sales value of these sheep for the debt owed to Salavan. ${ }^{71}$ Upon receiving similar orders, the district governor of Saruhan and the members of the local assembly informed the Sublime Porte that members of the Cihanbeyli and Zeyveli tribes had sold a considerable number of sheep in the region. Although a portion of the sales value had been given to the tribesmen by the butchers prior to the local authorities' investigation, the rest was to be

68 BOA: I.MSM 26/748, Recep 12, 1264 (June 14, 1848).

691 para amounted to $1 / 40$ of a piaster (kuruş), while 1 klyye/okka was equivalent to approximately $1.28 \mathrm{~kg}$.

70 BOA: I.MSM 26/748, Recep 12, 1264 (June 14, 1848).

71 BOA: A.MKT 148/94, Şevval 19, 1264 (September 18, 1848). 
confiscated for Salavan. ${ }^{72}$ The Sublime Porte investigated whether or not these sheep really belonged to the Cihanbeyli by questioning Ömer Bey, Alişan Bey's son, who was in İstanbul at the time. When Ömer Bey confirmed that the said individuals were members of the Cihanbeyli, the remaining sum was ordered to be confiscated by the local authorities. ${ }^{73}$

Despite the Sublime Porte's orders to exempt tribes other than the Cihanbeyli and Zeyveli from confiscation procedures, orders that aimed to facilitate sheep trade by the exempt tribes, nevertheless merchants from different backgrounds encountered several difficulties due to the debt crisis. Savalan, who had a vast network, tried to collect his debt as soon as possible. Thus, his representatives confiscated the transaction documents concerning the sale of sheep belonging to several merchants involved in sheep trade from central through western Anatolia. One such confiscation concerned the merchants of the Hecbanl and Seyfanlı tribes, who belonged to the Cihanbeyli confederation. These tribes had paid their share of the debt to Savalan, and according to the central government's orders, their sheep and transaction documents were to be exempt from confiscation. Nevertheless, the sales documents indicating the sums owed to members of the Hecbanl 1 and Seyfanl tribes for their sale of sheep in İstanbul, which amounted to 34,000 piasters, were confiscated by one of Savalan's representatives. Several butchers in Gebze had bought sheep from the Hecbanl 1 and Seyfanlı tribes, but had not yet paid these transactions. Savalan's representative had also collected these sums from the butchers in Gebze. ${ }^{74}$ When the tribes registered complaints, the director of the sheep tax sent an order to the district governor of İzmit, underscoring how the confiscation procedure could only be carried out with regard to the sheep and transaction documents of merchants of the Cihanbeyli and Zeyveli tribes. As such, the district governor was ordered to return the registered properties and money to the Hecbanl 1 and Seyfanll. ${ }^{75}$

In this process, problems were encountered not only by the merchants of the tribes associated with the Cihanbeyli, but also by several other merchants involved in the sheep trade from central Anatolia to the western parts of the empire. For example, the transaction cost of sheep brought from Esbikesan to Bursa by a merchant named Hacı Ömer, was not a member of the Cihanbeyli confederation, was confiscated for the Cihanbeyli tribes' debt owed to Savalan. The sum of the transaction value of these sheep amounted to 27,452 piasters. Although the central authorities discovered that the sheep involved in this transaction did not in fact belong to the Cihanbeyli and sent orders to the

72 BOA: A.MKT 167/9, Muharrem 13, 1265 (December 9, 1848).

73 BOA: A.MKT 167/9, Safer 6, 1265 (January 1, 1849).

74 BOA: A.MKT 164/88, Muharrem 15, 1265 (December 11, 1848).

75 BOA: A.MKT 164/88, Muharrem 19, 1265 (December 15, 1848). 
local authorities to return what had been confiscated, the money had already been delivered to Savalan by the time Hac1 Ömer Bey arrived in Bursa. The central authorities then sent orders to collect the sum owed to Hac1 Ömer from the Cihanbeyli tribe. ${ }^{76}$

The payment of the Cihanbeyli debt owed to Savalan also complicated relations among the tribes themselves, on the one hand, and relations between the tribes and local authorities, on the other. An interesting event illuminating such complications concerns the sale of 4,307 sheep sent by Alişan Bey to Ankara for partial payment of his share of the debt. These sheep were specifically sent for the debt, and in line with the procedure adopted for the debt collection, they would be sold in Ankara, with the value of the transaction to be transferred to Savalan under the supervision of local authorities. Naci Bey, one of the members of the local Ankara council, sold these sheep to members of the Zeyveli tribe for 122,605 piasters and guaranteed the payment of the transaction value in the local assembly. When the sum was subsequently demanded from Naci Bey, he objected to making the payment. It seems that he denied his responsibility as a guarantor, despite the fact that he had previously sworn as a guarantor. In the order that the Sublime Porte sent to the governor of Ankara regarding this issue, the local council was authorized to resolve the matter, declaring that if Naci Bey had been involved in the transaction in any way as a guarantor, then the sum must be collected from him. ${ }^{77}$

The documents pertaining to the case also indicate that the Cihanbeyli and Zeyveli tribes, whose sheep trade was now under strict control and intense pressure, developed several methods to avoid having their sheep confiscated. One such method was to secretly sell the sheep to butchers. One investigation ordered by the director of the sheep tax found that the value of such secret sales by Cihanbeyli tribesmen in Bursa amounted to 200,000 piasters. The field marshal of the province of Hüdavendigar was ordered to investigate this matter and to transfer the value of these secret sales, in addition to the value of the registered sales by the Cihanbeyli, which amounted to 431,817 piasters, to Savalan's representative rather than to the tribesmen. ${ }^{78}$

The second installment of the debt owed to Savalan was due on November 7 , 1848. This installment was not paid on time, either. After completing his official duty in the region, the state agent Ruhi Efendi prepared a table showing the sums received for the collection of the debt through various means, including the payments made to him in cash and kind as well as the confiscation of sheep

76 BOA: A.MKT.UM 13/100, Cemaziyelahir 12, 1266 (April 25, 1850) and Cemaziyelahir 18, 1266 (May 1, 1850).

77 BOA: A.MKT 148/94, Şevval 19, 1264 (September 18, 1848).

78 BOA: A.MKT 182/48, Rebiülahir 23, 1265 (March 18, 1849). 
transported by the tribes. According to his estimations, the total sum collected amounted to 772,267 piasters. This was almost 200,000 piasters short of the total due - that is, 972,000 piasters, with interest. ${ }^{79}$ But in a telegram sent to the Sublime Porte on May 31, 1849, Cemal Efendi and Alişan Bey reported that the sum of the collected debt amounted to 861,060 piasters. Following deliveries by the tribe's merchants to Bursa and İzmir, Savalan was still owed 9,641 piasters. The telegram noted that the Cihanbeyli had sent a great many sheep to various localities, and that the transaction value of these sheep continued to be confiscated. Concerned by the possibility of facing confiscation even after the finalization of debt payments, the tribes sent Molla Ömer from the Zeyveli tribe to İstanbul to check the registers and collect the sum that would remain after balancing the debt owed to Savalan. Cemal Efendi and Alişan Bey reported that, unless the remaining sum was paid to the tribes after the books had been balanced, they would not send sheep to İstanbul again. They requested the central authorities to assist Molla Ömer in his dealings with the relevant officials. Otherwise, they emphasized, the supply of meat to İstanbul might be disrupted, and "this situation would put the inhabitants of İstanbul in distress." 80 This emphasis indicates that the tribes were well aware of the importance the state attached to maintaining İstanbul's meat supply, and also of their central role in the capital's provisioning: they therefore used this as leverage to negotiate the terms of their trade with the Sublime Porte.

To recap, in the period following Savalan's confiscation of the transaction value of sheep transported to İstanbul by the Zeyveli in 1846, the central government tried to find a solution to the debt crisis between Savalan and the Cihanbeyli in a way that would not disrupt the meat supply of İstanbul. During this process, government officials attempted to secure the payment of Savalan's debt, but they were not hesitant to deepen the extent of intratribal debt. The initiatives taken by the government to separate the cases of the Cihanbeyli and Zeyveli from those of the other tribes, as well as the abuses and complications that accompanied the process of confiscation, undermined Alişan Bey's standing as chieftain of the Cihanbeyli. In fact, it can be argued that the central government's attempts to promote sheep trade among the remaining tribes hastened the decline in Alişan Bey's standing. In 1852, a few years after the books had been balanced between the Cihanbeyli and Savalan, the Ottoman center gradually began to decrease Alişan Bey's power, first by appointing headmen to their localities and finally by directly dismissing Alişan Bey himself, after which Salahaddin Agha, a local notable in Ankara, was appointed as the Cihanbeyli chief. Alişan Bey's tacit acceptance of his

79 BOA: A.MKT 220/82, no date.

80 BOA: A.MKT 220/82, Recep 9, 1265 (May 31, 1849). 
dismissal from the chieftainship was rewarded with the governorship of Kirşehir in 1852 - a position whose power fell significantly short of the power and influence he had exercised before. The dismissal of Alişan Bey was an important step toward the sedentarization of the Cihanbeyli. In 1860, the separate administrative unit of the Cihanbeyli was abolished and the tribal units were incorporated into the towns and villages where they resided. Several sections of the tribe were settled in villages in the town of Esbikesan in Konya, but most went to the district of Koçgiri in Sivas. ${ }^{81}$

While the debt owed to Savalan had been mostly paid by 1849 , there were several merchants whose transaction documents were confiscated afterward, despite their not being associated with the Cihanbeyli in any way. Such cases continued well into the $1850 \mathrm{~s} .{ }^{82}$ As late as 1858 , there were merchants whose sheep had been confiscated as part of the debt crisis who were still trying to secure the payment of the sums owed them by the Cihanbeyli and the Zeyveli.

After the settlement of the Cihanbeyli tribe and the end of the meat provisioning system, the tribe's sheep trade to İstanbul and other cities shrank to a great extent. The tribe had been dispersed across several regions around Konya and Sivas during the settlement process, and their agreement with the government to bring sheep to İstanbul for meat came to an end. Despite this dispersion and the termination of the agreement, however, some tribal merchants continued to be involved in the sheep trade. ${ }^{83}$

\section{Conclusion}

The above description and analysis of the sheep trade of the Cihanbeyli tribe raises several important issues and conclusions relevant to both the Ottoman economy and Ottoman politics. First of all, although the Tanzimat era is known for the adoption of liberal economic policies, the case of the Cihanbeyli shows that state intervention in the İstanbul market continued until the late 1850s. Provisioning meat for the imperial capital was still an important concern for the state during this period in spite of the rise of a free market economy. This is an important finding, and it leads to further questions. For instance, when meat provisioning came to an end in 1857, how were the needs of the palace, the army, officials, and the ordinary residents of İstanbul met? What effects did the elimination of provisioning have on these diverse groups? These questions call for further research, and they may serve as the topic of another paper in future.

81 Köksal, "Coercion and Mediation," 483.

82 BOA: A.MKT.UM 323/2, Muharrem 14, 1275 (August 24, 1858).

83 BOA: DH.MKT 1444/60, Ağustos 11, 1303 (August 23, 1887). 
Second, the analysis of the Cihanbeyli sheep trade supports the argument that tribes were an integral part of the imperial economy, politics, and society. In fact, the dependence of the Ottoman state on the Cihanbeyli's meat supply increased significantly from the seventeenth to the mid-nineteenth century. This opposes the conventional view that posits tribes as primordial forms hindering economic and social development during the modernization processes of the nineteenth and twentieth centuries. What we have found is that the Cihanbeyli were in fact a crucial player in the empire's meat trade extending over a large regional scale, from İstanbul to Bursa. Tribal leaders, headmen, and merchants became part of an imperial network and actively participated in the economic life of the empire, and tribal agents and representatives communicated directly with the authorities in İstanbul and with foreign and non-Muslim merchants and moneylenders. This picture challenges the view that sees tribes as isolated, backward entities. The debt crisis contributed directly to the dismissal of the tribal chief Alişan Bey, which then facilitated and in fact led to the sedentarization of the Cihanbeyli. The tribe's settlement spelled the end of their primary economic activity-that is, sheep trading to İstanbul. This process coincided with the end of the meat provisioning system of the imperial capital in 1857. Although no archival document has yet been found to support this claim, there is nevertheless a possibility that the end of the meat provisioning of civil servants and the relaxation of state pressure on İstanbul's meat prices were related to these tribal settlements. Provisioning became more difficult when the tribes were sedentarized, even though different forms of animal trade by the Cihanbeyli continued in Istanbul. Further studies on this topic may show how the Ottoman state was able to replace the lost animal supply. Finally, the article has shown that members of the Cihanbeyli, and especially their tribal leaders and headmen, were far from being merely passive agents or bystanders, but were indeed active agents. They constantly negotiated with state authorities, and they claimed their rights.

\section{References}

\section{Archival sources}

Ottoman Archives of the Republic of Turkey's Presidential State Archives

(Türkiye Cumburiyeti Cumburbaşkanlı̆̆ı, Devlet Arşivleri Başkanlı̆̆ı, Osmanlı Arşivleri; BOA)

A.M (Sadaret Müteferrik Belgeler)

A.MKT (Sadaret Mektubi Kalemi Evrakı) 
A.MKT.MVL (Sadaret Mektubi Kalemi Meclis-i Vala Evraki)

A.MKT.UM (Sadaret Mektubi Kalemi Umum Vilayat Evrakı)

AE.SSLM (Ali Emiri Yavuz Sultan Selim)

Ayniyat Defterleri

BEO (Bab-ı Ali Evrak Odasi)

C.BLD (Cevdet Belediye)

DH.MKT (Dabiliye Nezareti Mektubi Kalem)

HR.MKT (Hariciye Nezareti Mektubi Kalemi Evraki)

İ.MMS (İrade Meclis-i Mahsus)

İ.MSM (İrade Mesail-i Mühimme)

ŞD (Şura-yı Devlet Evrakı)

Y.PRK.AZJ (Yıldız Perakende Evrak Arzubal ve Jurnaller)

\section{Other sources}

Ahmed Cevdet Pasha. Mar'ûzât. Edited by Yusuf Halaçoğlu. İstanbul: Çağıı Yayınları, 1980.

Ahmed Cevdet Paşa. Tezâkir. 3 vols. Edited by Şevki Nezihi Aykut, Abdülkadir Özcan, and Mehmet İpşirli. Ankara: Türk Tarih Kurumu, 1991.

Ahmet Refik (Altınay). Anadolu'da Türk Aşiretleri (966-1200). İstanbul: Enderun, 1989.

Barakat, Nora Elizabeth. "An Empty Land? Nomads and Property Administration in Hamidian Syria." PhD diss., University of California, Berkeley, 2015.

- "Marginal Actors? The Role of Bedouin in Ottoman Administration of Animals as Property in the District of Salt, 1870-1912." Journal of the Economic and Social History of the Orient 58 (2015): 105-134.

Baran, Mamo. Koçgiri: Kuzey-Batı Dersim. İstanbul: Tohum, 2002.

Barkan, Ömer Lütfü. "Osmanlı İmparatorluğunda Bir İskan ve Kolonizasyon Metodu Olarak Sürgünler." Iktisat Fakültesi Mecmuası XI (1951); XIII (1953); XV (1955).

Barth, Fredrik. Nomads of South Persia: The Basseri Tribe of the Khamseh Confederacy. Boston: Little, Brown and Company, 1961.

Batatu, Hanna. The Old Social Classes and the Revolutionary Movement in Iraq. Princeton: Princeton University Press, 1978.

Beck, Lois. The Qashqa'i of Iran. New Haven: Yale University Press, 1974.

Cora, Yaşar Tolga. "Transforming Erzurum/Karın: The Social and Economic History of a Multiethnic Ottoman City in the Nineteenth Century." PhD diss., University of Chicago, 2016.

Çelik, Semih. "Scarcity and Misery at the Time of 'Abundance beyond Imagination': Climate Change, Famines and Empire-Building in Ottoman Anatolia (c. 1800-1850)." PhD diss., European University Institute, 2017.

Erler, Mehmet Yavuz. "Ankara ve Konya Vilayetlerinde Kuraklık ve Kıtlık (1845 ve 1875 Yılları)." PhD diss., Ondokuz Mayıs University, 1997.

Greenwood, Anthony. "istanbul's Meat Provisioning: A Study of the Celepkeşan System." PhD diss., University of Chicago, 1988. 
Haj, Samira. "The Problems of Tribalism: The Case of Nineteenth-Century Iraqi History." Social History 16, no. 1 (1991): 45-58.

Kabadayı, M. Erdem. "The Introduction of Merino Sheep Breeding in the Ottoman Empire: Successes and Failures." In Animals and People in the Ottoman Empire. Edited by Suraiya Faroqhi. İstanbul: Eren, 2010. 153-169.

Kasaba, Reşat. A Moveable Empire: Ottoman Nomads, Migrants and Refugees. Seattle: University of Washington Press, 2009.

Khoury, Philip S. and Joseph Kostiner, eds. Tribes and State Formation in the Middle East. Berkeley: University of California Press, 1990.

Köksal, Yonca. "Coercion and Mediation: Centralization and Sedentarization of Tribes in the Ottoman Empire." Middle Eastern Studies 42, no. 3 (2006): 469-491.

Lyberatos, Andreas. "Men of the Sultan: The Beğlik Sheep Tax Collection System and the Rise of a Bulgarian National Bourgeoisie in Nineteenth-century Plovdiv." Turkish Historical Review 1 (2010): 55-85.

Orhonlu, Cengiz. Osmanlı Imparatorluğunda Aşiretlerin İskanı. İstanbul: Eren, 1987.

Pamuk, Şevket. "Institutional Change and the Longevity of the Ottoman Empire, 1500-1800." Journal of Interdisciplinary History 35 (2004): 225-247.

- The Ottoman Empire and European Capitalism, 1820-1913: Trade, Investment, and Production. Cambridge: Cambridge University Press, 1987.

Perrot, Georges. "Les Kurdes de l'Haimaneh," Revue des Deux Mondes (February 1865): 607-631.

Rogan, Eugene L. Frontiers of the State in the Late Ottoman Empire: Transjordan, 1850-1921. Cambridge: Cambridge University Press, 1999.

Saylan, Kemal. "Licese Maden Ocağı ve Asia Minor Mining Company'nin Licese'deki Faaliyetleri." Tarih Incelemeleri Dergisi XXIX, no. 2 (2014): 625-643.

Schaebler, Birgit. "State(s) Power and the Druzes: Integration and the Struggle for Social control (18381949)." In the Syrian Land: Processes of Integration and Fragmentation. Edited by Thomas Philipp and Birgit Schaebler. Berlin: Franz Steiner, 1998. 331-365.

Shaw, Stanford J. "The Nineteenth-Century Ottoman Tax Reforms and Revenue System." International Journal of Middle East Studies 6, no. 4 (1975): 421-459.

Shields, Sarah D. "Sheep, Nomads and Merchants in Nineteenth-Century Mosul: Creating Transformations in an Ottoman Society." Journal of Social History 25, no. 4 (1992): 773-789.

Sykes, Mark. "The Kurdish Tribes of the Ottoman Empire." The Journal of the Royal Anthropological Institute of Great Britain and Ireland 38 (1908): 451-486.

Tapper, Richard. Pasture and Politics: Economics, Conflict and Ritual among Shahsevan Nomads of Northwestern Iran. London: Academic Press, 1979.

Uzun, Ahmet. İstanbul'un laşesinde Devletin Rolü: Ondalık Ağnam Uygulaması 1783-1857. Ankara, Türk Tarih Kurumu, 2006. 